\title{
Developing an English Teaching Model Using Project-Based Learning for SMA Students in Surakarta
}

\author{
Ngadiso Sutomo \\ English Education Department \\ Teacher Training and Education \\ Faculty \\ Surakarta, Indonesia \\ ngadisodok@yahoo.com
}

\author{
Teguh Sarosa \\ English Education Department \\ Teacher Training and Education \\ Faculty \\ Surakarta, Indonesia \\ teguhsrs@yahoo.com
}

\author{
Muhamad Asrori \\ English Education Department \\ Teacher Training and Education \\ Faculty \\ Surakarta, Indonesia \\ asrori_asli@yahoo.co.id
}

\begin{abstract}
English teachers of SMA must use Curriculum 13 for teaching English. In the early implementation of the curriculum, the teachers must use scientific approach. Nowadays, scientific approach is not the only approach to teach English using Curriculum 13. English teachers may also use the other approaches; one of them is project-based learning. That is why, it is necessary to conduct a research to develop a model of teaching English using project-based learning to help English teachers teach English to SMA students in Surakarta. The objectives of the research are: (1) to study the quality of the existing model for teaching English in SMA Surakarta; and (2) to develop a model for teaching English using project-based learning which is feasible to develop the students' four English skills. The research method used is Research and Development. Because it is an educational research, it is classified as Educational Research and Development. The results of the research in the first year show that there are still some weaknesses of the existing model for teaching English, so it is necessary to design the prototype for teaching English using projectbased learning. The prototype is tried out until it becomes a feasible model for the teacher to teach English, for the students to study English, and for developing the students, four English skills (listening, reading, speaking, dan writing).
\end{abstract}

Keywords: project-based learning; teaching four English skills

\section{INTRODUCTION}

English teachers of SMA must use Curriculum 13 for teaching English. In the early implementation of the curriculum, the teachers must use scientific approach. Nowadays, scientific approach is not the only approach to teach English using Curriculum 13. English teachers may also use the other approaches; one of them is project-based learning. Project-based learning (PBL) is a learning strategy which is organized around projects in the form of complex tasks based on challenging questions or problems. The students conduct an exploration, interpretation, and synthesis to achieve the learning objectives. That is why it is necessary to design an English teaching model using project-based learning which can develop the students' four English skills (listening, reading, speaking, and writing) simultaneously.

The objective of the research is to design an English teaching model using project-based learning which can develop the students' four English skills simultaneously. To design the appropriate teaching model, it is necessary to investigate the existing condition to find out the problems/weaknesses and to conduct need analysis so that the design can overcome the problems and fulfill what is really needed. Based on the problems/weaknesses and need analysis, a prototype of English teaching model is designed. The prototype is then tried out and revised based on the result of observation and FGD. The revised model is tried out again and revised until it becomes a feasible model for the teacher to teach English, for the students to study English, and for developing the students' four English skills.

The development of an English teaching model is carried out through Research and Development. The expected findings of the research in the first year are: (1) the weaknesses of the existing teaching model; and (2) the prototype of an English teaching model using project-based learning. The expected finding of the research in the second year is the feasible model for the teacher to teach English, for the students to study English, and for developing the students' four English skills. The research findings can be used by English teachers in SMA Surakarta as the stakeholders of higher education (Sebelas Maret University) to conduct English teaching and learning process to develop the students' four English skills simultaneously.

To support the implementation of Research and Development and to design an English teaching model using project-based learning, it is necessary to conduct literature review. Based on Permendikbud (Ministry of Education and Culture) No. 65/2013, teaching and learning process uses learning models, media, and resources which are appropriate with the students' characteristics and the lesson. The approaches chosen by the teachers whether thematic 
and/or integrated thematic, discovery, or projectbased learning are based on the students' characteristics, the lesson, competency, and education levels. Project-based learning (PBL) is one of them which will be used in this research.

Project-based learning (PBL) is simply defined as a learning strategy which is organized around projects (Bell, 2010). Thomas (2000) stated that project-based learning (PBL) is a model that organizes learning around projects which are complex tasks based on challenging questions or problems. According to Ministry of Education and Culture, project-based learning (PBL) is a teaching method using a project as the media. The students conduct an exploration, interpretation, and synthesis to achieve the learning objectives. It is initiated by the problems to get and integrate the new knowledge based on their experience in real life activities. PBL is designed to solve the complex problems and inquiry process is conducted based on a guiding question which guides the students to conduct collaborative project integrating various subjects in a curriculum. PBLis a deep investigation of the real world topic which is useful for the students.

There are five criteria of PBL according to Thomas (2000) as follows: (1) PBL projects are central, not peripheral to the curriculum; (2) PBL projects are focused on questions or problems that drive the students to encounter (and struggle with) the central concepts and principles of a discipline; (3) Projects involve students in a constructive investigation; (4) Projects are student-driven to some significant degree; and (5) Projects are realistic, not school-like. According to Ministry of Education and Culture, the main characteristics of PBL are as follows: (1) it is student-centered; (2) it is communicative because they must communicate in conducting the project; (3) it is contextual; and (4) it develops their soft skill.

There are some benefits of PBL. It offers many opportunities to promote language use and acquisition in real-life contexts because the basic premise of PBL is that learning begins with a problem presented in the same context as it will be encountered in real life (Kumaravadivelu, 2001). According to Ministry of Education and Culture, the benefits of PBL for the students are as follows: (1) increasing their learning motivation and encouraging them to conduct an important work; (2) improving their ability to solve the problem; (3) making them more active and successful in solving complex problems; (4) improving collaboration; (5) encouraging them to develop and practice their communication skill; (6) improving their skill to manage the resources; (7) giving them experiences in learning and organizing the projects, especially in allocating the time and other resources to finish the projects; (8) providing learning experience for living in the real world; (9) activating them to implement their knowledge in the real world; and (10) making learning more interesting so that both students and the teacher enjoy the teaching and learning process.

In real-life contexts or in daily life, it rarely or never happens to communicate with only one language skill. The person tends to use two or more language skills to interact with other persons. It also happens in learning English using project-based learning. Kumaravadivelu (2003) stated "projectbased activities stresses interactive language use that requires a synthesis of various language skills and various language components". Imtiaz and Asif (2012) proved that PBL played an important role in improving students' language skills and promoting students' autonomous learning skill. Stoller (2006) stated that PBL provides opportunities for the natural integration of all four skills: reading, writing, listening, and speaking. Sbmirshojaee (2010) stated "The integrative approach provides an authentic language environment for learners to develop language skills in a meaningful context by building on learners' prior knowledge on interesting and relevant topics". An integrated model gives a natural learning nuance and large chance to the learners to develop four English skills.

Brown (2000) stated that the characteristics of integrated learning are as follows: (1) Production and reception are quite simply two sides of the coin: one cannot split the coin into two; (2) Interaction means sending and receiving messages; (3) Written and spoken language often bear a relationship to each other; to ignore that relationship is to ignore the richness of language; (4) For literate learners, the interrelationship of written and spoken language is an intrinsically motivating reflection of language and culture and society; (5) By attending primarily to what learners can do with language, and only secondarily to the forms of language, we invite any or all of the four skills that are relevant into the classroom arena; (6) Often one skill will reinforce another; we learn to speak, for example, in part by modelling what we hear, and we learn to write by examining what we have read; and (7) Proponents of the whole language approach have shown us that in the real world of language use, most of our natural performance involves not only the integration of one or more skills, but also connections between language and the way we think and feel and act.

Kumaravadivelu (2003) stated the macro strategies of integrative learning as follows: (1) Maximize learning opportunities: this macro strategy envisages teaching as a process of creating and utilizing learning opportunities, a process in which teachers strike a balance between their role as managers of teaching acts and their role as mediators of learning acts; (2) Minimize perceptual mismatches: this macro strategy emphasizes the recognition of potential perceptual mismatches between intentions and interpretations of the learner, the teacher, and the 
teacher educator; (3) Facilitate negotiated interaction: this macro strategy refers to meaningful learnerlearner, and learner-teacher classroom interaction in which learners are entitled and encouraged to initiate topic and talk, not just react and respond; (4) Promote learners' autonomy: this macro strategy involves helping learners learn how to learn, equipping them with the means necessary to self-direct and selfmonitor their own learning; (5) Foster language awareness: this macro strategy refers to any attempt to draw learners' attention to the formal and functional properties of their L2 in order to increase the degree of explicitness required to promote L2 learning; (6) Activate intuitive heuristics: this macro strategy highlights the importance of providing rich textual data so that learners can infer and internalize underlying rules governing grammatical usage and communicative use; (7) Contextualize linguistic input: this macro strategy highlights how language usage and use are shaped by linguistic, extra linguistic, situational, and extra situational contexts; (8) Integrate language skills: this macro strategy refers to the need to holistically integrate language skills traditionally separated and sequenced as listening, speaking, reading, and writing; (9) Ensure social relevance: this macro strategy refers to the need for teachers to be sensitive to the societal, political, economic, and educational environment in which L2 learning and teaching take place; and (10) Raise cultural consciousness: this macro strategy emphasizes the need to treat learners as cultural informants so that they are encouraged to engage in a process of classroom participation that puts a premium on their power/knowledge.

Kumaravadivelu (2003) stated the teaching steps of integrated learning as follows: (1) Try to understand the teacher's directions, seek clarifications, and take notes (listening, speaking, and writing); (2) Brainstorm, in pairs or in small groups, and decide to use library resources or the internet to collect additional information (listening, speaking, reading, and writing); (3) Engage in a decisionmaking process about how to use the collected information and proceed with the activities (listening, speaking, and reading); (4) Carry out their plan of actions (reading, writing, speaking, and listening); (5) Use the notes taken during their group discussion and present to class what they have accomplished (reading, speaking, and listening); and (6) Finish the activity with a whole class discussion (listening and speaking).

Stix and Hrbek (2004) stated the teaching steps of PBL as follows: (1) The teacher sets the stage for students with real-life samples of the projects they will be doing; (2) Students take on the role of project designers, possibly establishing a forum for display or competition; (3) Students discuss and accumulate the background information needed for their designs; (4) The teacher and students negotiate the criteria for evaluating the projects; (5) Students accumulate the materials necessary for the project; (6) Students create their projects; (7) Students prepare to present their projects; (8) Students present their projects; and (9) Students reflect on the process and evaluate the projects based on the criteria established in Step 4

Stoller (1997) stated the teaching steps of PBL as follows: (1) Students and teacher agree on a theme for the project; (2) Students and teacher determine the final outcome of the project; (3) Students and teacher structure the project; (4) Teacher prepares students for the demands of information gathering; (5) Students gather information; (6) Teacher prepares students to compile and analyze data; (7) Students compile and analyze information; (8) Teacher prepares students for the language demands of the final activity; (9) Students present the final product; and (10) Students evaluate the project.

According to Ministry of Education and Culture, the teaching steps of PBL are as follows: (1) The teacher determines the competence which will be developed; (2) The teacher explains the vocabulary which will be developed such as prepositional phrasal verbs (go up, look for, and take away); (3) The teacher explains the meaning of prepotional phrasal verbs and how to use them in sentences; (4) The teacher explains the project which must be conducted by the individual students to find prepotional phrasal verbs; (5) The students present the result of the project in front of the class; (6) The teacher divides the students into pairs and each pair should construct a dialog using prepositional phrasal verbs; (7) Each pair performs the dialog in front of the class; and (8) The other pairs and the teacher give feedback and correction.

By using PBL which is also integrative learning, the English teacher integrates the four English skills and develops the indicators of each skill. The following are the indicators which should be developed in teaching English skills (Joko Nurkamto, et al., 2012, pp. 46-48). The indicators of listening skill are as follows: (1) Finding the main idea of a text or paragraph; (2) Determining the communicative purpose; (3 Finding the explicit information; (4) Finding the implicit information; (5) Explaining the meaning of words or expressions in a text (contextual meaning); and (6) Explaining the reference of a pronoun in a text.

The indicators of reading skill are as follows: (1) Finding the main idea of a text or paragraph; (2) Determining the communicative purpose; (3) Finding the explicit information; (4) Finding the implicit information; (5) Explaining the meaning of words or expressions in a text (contextual meaning); and (6) Explaining the reference of a pronoun in a text.

The indicators of speaking skill are as follows: (1) Stating the main idea of the speech; (2) Providing supporting details of the topic/idea; (3) Using 
appropriate words, phrases, or utterances to express the idea; (4) Using certain language system (grammar) to make well-formed utterances; and (5) Performing acceptable pronunciation to express understandable utterances.

\section{MATERIALS AND METHODS}

The research method used was Research and Development. Because it is included in educational research, it is classified as Educational Research and Development. Gall, Gall, and Borg (2003, p. 569) defined Educational R \& $\mathrm{D}$ as an industry-based development model in which the findings of the research are used to design new products and procedures, which are systematically field-tested, evaluated, and refined until they meet specified criteria of effectiveness, quality, or similar standard. Gall, Gall, and Borg (2003, p. 772) also defined Educational R \& D as a process used to develop and validate educational products. The steps of this process are usually referred to as the $\mathrm{R} \& \mathrm{D}$ cycle, which consists of studying research findings pertinent to the product to be developed, developing the product based on these findings, field testing it in the setting where it will be used eventually, and revising to correct the deficiencies found in the field-testing stage. In more rigorous programs of $\mathrm{R} \& \mathrm{D}$, this cycle is repeated until the field-test data indicate that the product meets its behaviorally defined objectives. As stated by Gall, Gall, and Borg (2003: 772), the term product refers to not only material objects (textbooks, films, etc.) but also procedure and process (teaching methods).

Gall, Gall, and Borg (2003, pp. 775-776) also stated that the stages and cycles of $\mathrm{R} \& \mathrm{D}$ in education are as follows: (1) Research and information collecting: review of literature, classroom observations, and preparation of report of state of the art; (2) Planning: defining skills, stating objectives, determining course sequence, and small scale feasibility testing; (3) Developing preliminary form of product: preparation of instructional material, handbooks, and evaluation devices; (4) Preliminary field testing: conducted in 1 to 3 schools, using 6 to 12 subjects. Interview, observational, and questionnaire data are collected and analyzed; (5) Main product revision: revision of product as suggested by the results of the preliminary field-test; (6) Main field testing: conducted in 5 to 15 schools with 30 to 100 subjects. Quantitative data on subjects' pre-course and post-course performance are collected. Results are evaluated with respect to course objectives and compared with control group data, when appropriate; (7) Operational product revision: revisions of product as suggested by main field-test results; (8) Operational field testing: conducted in 10 to 30 schools involving 40 to 200 subjects. Interview, observational, and questionnaire data are collected and analyzed; (9) Final product revision: revision of product as suggested by operational field-test results; and (10) Dissemination and implementation: report on product at professional meetings and in journals. Work with publisher who assumes commercial distribution. Monitor distribution to provide quality control.

After studying the stages and cycles of R \& D stated by Gall, Gall, and Borg (2003), the researchers used three stages as follows: (1) exploration stage, (2) development stage, and (3) experiment stage. All the three stages are conducted in three years as follows: (1) the first stage was conducted in 2018 to find out the weaknesses of the existing model used in teaching English in SMA Surakarta and to conduct need analyses to develop the prototype of teaching English using project-based learning; (2) the second stage will be conducted in 2019 to try out the prototype of teaching English using project-based learning until it becomes a feasible model for the teacher to teach English, for the students to study English, and for developing the students' four English skills; and (3) the third stage will be conducted in 2020 to compare the existing model and the developed model of teaching English using project-based learning and to find out which one is more effective to teach English or for developing the students' four English skills. The data were collected using observation, questionnaire, interview, and FGD; validated using prolonged engagement, researchers' alertness, member checking, and triangulation; and analyzed using constant comparative method consisting of: (1) determining units of information; (2) making information categories based on the similarities; (3) determining the relationship among categories; and (4) developing theories based on the relationship types among information categories.

\section{RESULTS AND DISCUSSION}

The research findings of the first stage are: (a) the weaknesses of the existing model for teaching English in SMA Surakarta; and (b) the prototype of teaching English using project-based learning.

a. The weaknesses of the existing model of teaching English conducted in SMA Surakarta

Based on the results of observation, questionnaire, interview, and FGD, the weaknesses of the existing model of teaching English conducted in SMA Surakarta are as follows:

1) It takes much time using genre-based approach to finish the materials

2) There are too many learning materials which should be taught integratedly

3) It is difficult to find out the theme which is appropriate with material

4) There are no sufficient facilities

5) The teaching method cannot optimally develop the students' vocabulary mastery so it is difficult and takes much time for them to make sentences 
6) The existing method demands the students to master not only English skill but also other skills like ICT

7) The existing method is not interesting for the students

8) The existing method cannot optimally develop the students' abilities and skills

9) The existing method is teacher-centered so it tends to make students passive, bored, and unmotivated

10) The English teachers emphasize on reading and writing skills

11) The English teachers cannot develop all indicators of each English skill

12) The English teachers cannot optimally create an interesting teaching and learning process

13) The English teachers still need to explain and give a model to the students

14) The students' participation is not optimal

15) Some students cannot work collaboratively

16) Some students are sleepy and bored so they tend to chat because the learning activities are not interesting and innovative

17) The class situation is noisy because some groups are not doing the task and some members are chatting

18) Some students cannot concentrate on the lesson because the other students are noisy

19) It is difficult for the English teachers to score the students' speaking skill

20) The English teachers have not really understood the steps of teaching English using project-based learning

b. The prototype of teaching English using projectbased learning

Based on the existing condition and weaknesses, the researcher designed the prototype of teaching English using project-based learning to develop the students' four English skills (listening, reading, speaking, and writing), as follows:

1) The teacher sets the stage for students with reallife samples of the projects they will be doing

2) Students and teacher agree on a theme for the project

3) Students and teacher determine the final outcome of the project

4) The teacher prepares students for the language demands of the final activity

5) The teacher and students negotiate the criteria for evaluating the projects

6) Students and the teacher structure the project

7) Teacher prepares students for the demands of information gathering

8) Students take on the role of project designers, possibly establishing a forum for display or competition

9) Students discuss and accumulate the background information needed for their designs

10) Students accumulate the materials necessary for the project
11) The teacher prepares students to compile and analyze data

12) Students compile and analyze information

13) Students create their projects

14) Students prepare to present their projects

15) Students present their projects

16) Students evaluate the final product of the project

17) Students reflect on the process

The prototype will be elaborated in the form of lesson plan for teaching English to develop the students' four English skills (Joko Nurkamto, et al., 2012, pp. 46-48 and Brown, 2000, pp. 247-360). The prototype will be tried out in English class of SMA 1 Surakarta which will be observed by the researchers and followed by FGD and revision. The revised prototype will be then tried out in SMA 7 which will be observed by the researchers and followed by FGD and revision. The revised prototype will be tried out again in SMA Batik 2 Surakarta which will be observed by the researchers and followed by FGD and revision until the prototype is feasible for the teacher to teach English, for the students to study English, and for developing the students' four English skills.

\section{CONCLUSIONS}

The conclusions which can be drawn from the research findings are as follows:

1. There were 20 weaknesses of the existing teaching model used by the English teachers to teach English so that it could not develop the students' four English skills simultaneously and it is necessary to develop a teaching model for teaching English using project-based learning which can develop the students' four English skills simultaneously.

2. The developed model for teaching English will be feasible for the teacher to teach English, for the students to study English, and for developing the students' four English skills (listening, reading, speaking, and writing) simultaneously after it is tried out and revised based on the results of observation and FGD.

\section{ACKNOWLEDGMENT}

The paper is written based on the research which has been done because of the financial support from Sebelas Maret University and contributions of other colleagues and students who are not included in the authorship of this paper. The paper has not been published in the national and international journals and proceedings of national and international seminars.

\section{REFERENCES}

1. Bell, S. (2010). Project-based learning for the 21st century: Skills for the future. The Clearing House, 83(2), 39-43. 
2. H. D. Brown, Teaching by Principles: An Interactive Approach to Language Pedagogy (Pearson Education Inc., California, 2000), pp. 247-360.

3. Imtiaz, S. \& Asif, S. I. (2012). "I almost learnt to learn": Promoting Learner's Autonomy through Project Based Learning in Access Classrooms. Language in India 12.1, 2445.

4. Joko Nurkamto, et al., Modul Model-Model, Media, dan Evaluasi Pembelajaran Bahasa Inggris (UNS Press., Surakarta, 2012), pp. 46-48.

5. Kumaravadivelu, B. (2001). 'Toward a postmethod pedagogy.' TESOL Quarterly, vol 35, 537-560.

6. Kumaravadivelu, B. Beyond Methods: Macro Strategies for Language Teaching (Yale University Press, New Haven and London, 2003), pp. 225-238.

7. Meredith D. Gall, Joyce P. Gall, dan Walter R. Borg.Educational Research (Pearson Education, Inc., Boston, 2003), pp. 569-776.

8. Permendikbud (Ministry of Education and Culture) No. 54 Tahun 2013.

9. Permendikbud (Ministry of Education and Culture) No. 65 Tahun 2013.

10. Permendikbud (Ministry of Education and Culture) No. 68 Tahun 2013.

11. Permendikbud (Ministry of Education and Culture) No. 69 Tahun 2013.

12. Stix and Frank Hrbek (2004). Teachers as Classroom Coaches: Steps of Project Based learning (Online), Vol. 4, No 2 (http://Project.steps. based.Learning.edu/April 21, 2012.

13. Stoller, F. (1997). Project work: A means to promote language content, English Teaching Forum Online, 35(4), 1997. Retrieved September 10, 2009 from http://exchanges.state.gov/forum/vols/vol35/no4/p2.htm

14. Stoller, F. (2006). Establishing a theoretical foundation for project-based learning in second and foreign language contexts, in G. H. Beckett \& P. C. Miller (Eds.), ProjectBased Second and Foreign Language Education: past, present, and future (pp. 19-40), Information Age Publishing.

15. Thomas, J. W. (2000). A Review of Research on ProjectBased Learning. Retrieved September 10, 2009 from www.bobpearlman.org/BestPractices/PBLResearch.pdf. 